\title{
Acute Appendicitis with Perinephric Abscess - A Rare Occurrence
}

\author{
Azharuddin Mohd. ${ }^{1}$, Harpreet Singh Jolly², Subhash Goyal ${ }^{3}$ \\ ${ }^{1,3}$ Department of General Surgery, Prolife Hospitals, Gill Pind, Malerkotla Road, Ludhiana, Punjab, India. ${ }^{2}$ Department \\ of Laparoscopic and Bariatric Surgery, Prolife Hospitals, Gill Pind, Malerkotla Road, Ludhiana, Punjab, India.
}

\section{INTRODUCTION}

Vermiform appendix previously thought to be a vestigial organ, has a variable length of 2 - $20 \mathrm{cms}$. It arises from posteromedial wall of cecum, around $2 \mathrm{cms}$ lower than the ileocecal valve. The tip of appendix can be in different directions like retrocecal, pelvic, subcecal, retroileal, preileal, subhepatic and ectopic. ${ }^{1}$

The appendix is supplied by the appendicular artery, anterior and posterior cecal arteries. Ileocolic and right colic veins drain venous blood of appendix. Ileocolic lymph nodes adjacent to the superior mesenteric artery drains the lymphatics. ${ }^{2}$ Acute appendicitis remains the commonest cause of acute abdominal pain requiring surgical intervention. ${ }^{3}$ Acute appendicitis may present as loss of appetite, periumbilical pain, nausea and few episodes of vomiting, associated with low grade fever $\left(38^{\circ} \mathrm{C}\right)$, there is also signs of peritoneal inflammation in lower abdomen. ${ }^{4}$

Acute appendicitis is actually a clinical diagnosis and confirmed by laboratory investigations like neutrophilia and radiological studies like ultrasonography abdomen. ${ }^{5}$ Appendicular perforation, cecal perforation, gangrene, periappendicular abscess, peritonitis, bowel obstruction, septic seeding of mesenteric vessels, and very rarely perinephric abscess are the complications of acute appendicitis. ${ }^{6}$

Purulent collection between the kidney and Gerota's fascia is called as perinephric abscess, mostly occurs due to rupture of intrarenal abscess into the space between kidney and Gerota's fascia, few other causes of perinephric abscess include haematogenous spreading from other sites of infection and direct spread from adjacent viscera, perforated colon carcinoma, diverticulitis and osteomyelitis of adjacent ribs or vertebrae. ${ }^{7}$

\section{PRESENTATION OF CASE}

A male patient aged 22 years presented in the emergency department of Prolife Hospitals Ludhiana, with right lumbar pain and fever without history of trauma, urinary symptoms or any bowel disturbances. At admission patient was running low grade fever $\left(39^{\circ} \mathrm{C}\right)$ with heart rate of 110 / minute, respiratory rate 26 / minute and blood pressure 100 / $65 \mathrm{mmHg}$. On per abdominal examination abdomen was found soft and compressible with normal bowel sound. However, right loin and costovertebrae exhibited tenderness with fullness in the ipsilateral renal angle along with erythema. Haemoglobin was $11.8 \mathrm{~g} / \mathrm{dL}$ and hyper leukocytosis with predominant neutrophilia. Urine examination was grossly normal. Ultrasound abdomen was suggestive of mixed echotexture collection with gas shadows around right kidney with normal renal parenchyma. There was no intraperitoneal collection. Computed tomography of abdomen showed collection around right kidney with appendix tip lying in the collection (Figure 1).
Corresponding Author: Dr. Mohd. Azharuddin, Department of General Surgery, Prolife Hospitals Ludhiana, Gill Pind, Malerkotla Road, Ludhiana-141116,

Punjab, India.

E-mail:dr-azhar@hotmail.com

DOI: $10.14260 /$ jemds/2021/159

How to Cite This Article:

Mohd A, Jolly HS, Goyal S. Acute appendicitis with perinephric abscess - a rare occurrence. J Evolution Med Dent Sci 2021;10(10):743-745, 10.14260/jemds/2021/159

Submission 07-10-2020,

Peer Review 16-01-2021,

Acceptance 23-01-2021,

Published 08-03-2021.

Copyright (C) 2021 Azharuddin Mohd et al. This is an open access article distributed under Creative Commons Attribution License [Attribution 4.0 International (CC BY 4.0)] 


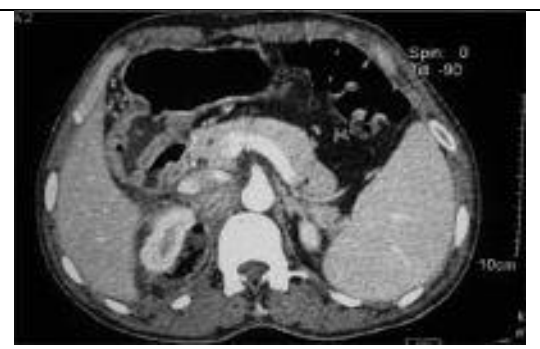

Figure 1.

Computed

Tomography

Abdomen Showing

Collection Around

Right Kidney with

Appendix Tip Lying in the Collection.

\section{CLINICAL DIAGNOSIS}

Right perinephric abscess.

\section{DIFFERENTIAL DIAGNOSIS}

Right perinephric abscess

Acute perforated appendix

Right psoas abscess extending to retroperitoneum.

\section{PATHOLOGICAL DISCUSSION}

Histopathological examination suggestive of perforated appendix with acute inflammation and faecolith within the lumen appendix. No evidence of carcinoid or malignant pathology was noted.

\section{DISCUSSION OF MANAGEMENT}

Aggressive broad-spectrum antibiotics and other supportive therapy was given prior to surgery. Patient was operated laparoscopically and about half litre of pus was drained from the right perinephric space (Figure 2). Perforated necrotic appendix (Figure 3) with faecolith (Figure 4) was removed and a drain was placed in the abscess cavity. His post-operative period was uneventful and recovered well.

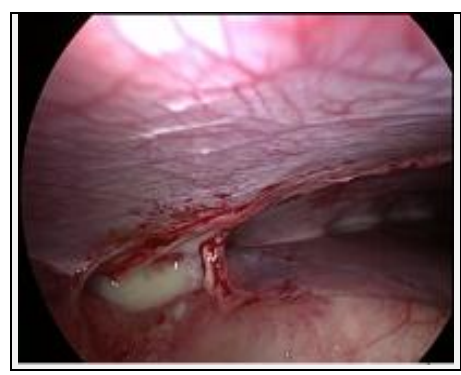

\section{Figure 2}

Showing Pus Collection in Right Perinephric Space

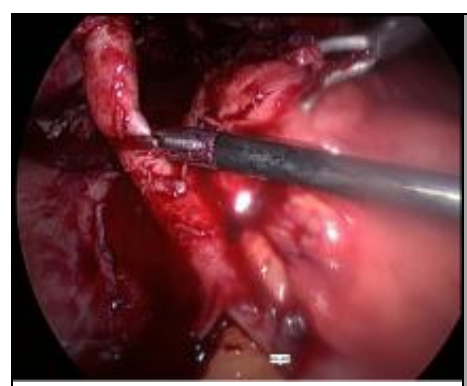

Figure 3.

Showing Inflamed Long

Retrocecal Appendix

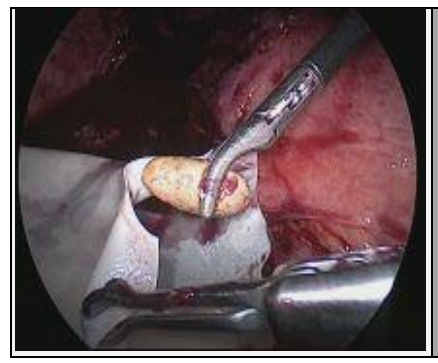

Figure 4.

Showing Faecolith Removed

from Appendix

\section{DISCUSSION}

Infections from urinary bladder ascends to result pyelonephritis leading to perinephric fat necrosis. It may also arise from non-renal contiguous infections due to polymicrobial pathogens from adjacent organs. ${ }^{8}$ Diabetes mellitus, pregnancy, urinary tract infections and structural abnormalities of urinary tract invites gram negative infestations to lead perinephric abscess. ${ }^{9}$ In good number of cases of perinephric abscess renal calculi remains the major culprit. Fever, fatigue, flank and abdominal pain are the common prodromal symptoms. A timely effective intervention by $3^{\text {rd }} / 4^{\text {th }}$ generation antibiotics may keep disastrous side effects in abeyance. ${ }^{10}$

Though perinephric abscess resulting from acute appendicitis is very rare, yet scanty literature is available to mention appendix as a causative culprit. 1,2,7,11,12

\section{FINAL DIAGNOSIS}

Perforated acute appendicitis with right perinephric abscess.

Financial or other competing interests: None.

Disclosure forms provided by the authors are available with the full text of this article at jemds.com.

\section{REFERENCES}

[1] Ghorbani A, Forouzesh M, Kazemifar AM. Variation in anatomical position of vermiform appendix among Iranian population: an old issue which has not lost its importance. Anat Res Int 2014;2014:313575.

[2] Deshmukh S, Verde F, Johnson PT, et al. Anatomical variants and pathologies of the vermin. Emerg Radiol 2014;21(5):543-52.

[3] Tan WJ, Acharyya S, Goh YC, et al. Prospective comparison of the alvarado score and CT scan in the evaluation of suspected appendicitis: a proposed algorithm to guide CT use. J Am Coll Surg 2015;220(2):218-24.

[4] Iamarino APM, Juliano Y, Rosa OM, et al. Risk factors associated with complications of acute appendicitis. Rev Coll Bras Cir 2017;44(6):560-66.

[5] Shogilev DJ, Duus N, Odom SR, et al. Diagnosing appendicitis: evidence-based review of the diagnostic approach in 2014. West J Emerg Med 2014;15(7):859-71.

[6] Leite NP, Pereira JM, Cunha R, et al. CT evaluation of appendicitis and its complications: imaging techniques 
and key diagnostic findings. AJR Am J Roentgenol 2005;185(2):406-17.

[7] Kao CT, Tsai JD, Lee HC, et al. Right perinephric abscess: a rare presentation of ruptured retrocecal appendicitis. Pediatr Nephrol 2002;17(3):177-80.

[8] Okafor CN, Onyeaso EE. Perinephric Abscess. In: Stat Pearls. Treasure Island (FL): Stat Pearls Publishing 2020.

[9] Gardiner RA, Gwynne RA, Roberts SA. Perinephric abscess. BJU Int 2011;107(Suppl 3):20-3.
[10] Lee BE, Seol HY, Kim TK, et al. Recent clinical overview of renal and perirenal abscesses in 56 consecutive cases. Korean J Intern Med 2008;23(3):140-8.

[11] Bologna RA, Khoudary KP, Danesis GG, et al. Acute appendicitis presenting as a perinephric abscess. J Urol 1996;156(5):1758.

[12] Wani NA, Farooq M, Gojwari T, et al. Perinephric abscess caused by ruptured retrocecal appendix: MDCT demonstration. Urol Ann 2010;2(1):29-31. 